\title{
RAZPRAVE
}

\section{LEHNJAKASTI KAPNIKI V SPODMOLIH V SLOVENSKI ISTRI}

\author{
AVTORJA \\ Leni Ozis \\ Jamova 50, SI - 1000 Ljubljana, Slovenija; leni.ozis@student.uni-lj.si \\ dr. Andrej Šmuc \\ Univerza $v$ Ljubljani, Naravoslovnotehniška fakulteta, Privoz 11, SI - 1000 Ljubljana, Slovenija \\ andrej.smuc@ntf.uni-lj.si
}

DOI: $10.3986 / G V 87201$

UDK: 551.43:552.545(497.472)

COBISS: 1.01

\section{IZVLEČEK}

\section{Lehnjakasti kapniki v spodmolih $v$ slovenski Istri}

Apnenčaste stene spodmolov $v$ slovenski Istri so pogosto prekrite s karbonatnimi tvorbami. Za te tvorbe so predhodno obstajale domneve, da gre za sige, naša domneva pa je, da so lehnjaki. Opravili smo raziskave tvorb na dveh lokacijah - Veli Badin in Stena v dolini Dragonje. Tvorbe smo fotografirali, izmerili in zabeležili posebnosti. V laboratoriju smo opravili petrološke, sedimentološke, mineraloške in geokemične analize tvorb. Ugotovili smo, da gre za poseben tip lehnjakov - lehnjakaste kapnike. Njihov nastanek je vezan na mikroklimatske pogoje, drugačne od tistih v jamah, na njihovo odlaganje pa vplivajo organizmi, ki preraščajo stene spodmolov. Prisotnost lehnjakov na izbranih lokacijah kaže, da spodmoli glede na morfologijo predstavljajo polodprti prostor tudi v predhodnih fazah njihovega razvoja.

\section{KLJUČNE BESEDE}

lehnjak, lehnjakasti kapniki, mahovni lehnjaki, spodmoli, Veli Badin, Stena v dolini Dragonje, slovenska Istra

\section{ABSTRACT}

\section{Tufaceous speleothems in rock shelters in Slovenian Istria}

The distinct feature of rock shelters in Slovenian Istria is that the host limestone rock is frequently overlain by freshwater calcareous deposits. These deposits were in the past described as speleothems, but our assumption was that these deposits are tufas. In our study we focused on two locations - Veli Badin and Stena in Dragonja Valley. Calcareous formations were photographed and measured in the field; an inventory of the specifics of formations was made. In the laboratory we made petrological, sedimentological, mineralogical and geochemical analyses of samples of the deposits. In contrast to previous assumptions the deposits represent a specific form of tufa - tufaceous speleothems. The formation of these tufas is related to microclimatic conditions, different from those in cave environment, and the presence of organisms, which have influence on tufa deposition. The presence of tufas corroborates the idea that rock shelters in their previous formation phases morphologically represented a semi-open space.

\section{KEY WORDS}

tufa, tufaceous speleothems, moss tufa, rock shelters, Veli Badin, Stena in Dragonja Valley, Slovenian Istria

Uredništvo je prispevek prejelo 14. marca 2015. 


\section{Uvod}

Stene spodmolov v slovenski Istri so pogosto prekrite s karbonatnimi tvorbami, za katere so obstajale domneve, da nastajajo $\mathrm{z}$ odlaganjem sige. Te sigove tvorbe se po literaturi pojavljajo v različnih oblikah, podobnih jamskim kapnikom: stalaktiti, sigova rebra oz. zavese, sigaste prevleke in grudaste tvorbe (Habič s sodelavci 1983; Kunaver in Ogrin 1992; 1993; Natek s sodelavci 1993; Grmovšek 2001; 2002; 2003; Gogala 2007; Kunaver 2007). Prisotnost sige naj bi dokazovala obstoj nekdanjih jamskih prostorov (Gogala 2007), katerih stene so pod vplivom delovanja erozijskih procesov delno odstranjene in preoblikovane v pol-odprti prostor oziroma pol jamski prostor (Kunaver 2007), ki ga morfološko predstavljajo spodmoli. Naša domneva pa je bila, da tvorbe niso sige, temveč lehnjaki, kar kaže na to, da tvorbe niso nastajale v nekdanjih jamskih prostorih, ampak na površju. $\mathrm{V}$ ta namen smo opravili detajlne raziskave na dveh lokacijah: Velem Badinu jugovzhodno od naselja Sočerga in Steni južno od naselja Dragonja. Na obeh lokacijah se na stenah spodmolov pojavljajo številne tvorbe različnih velikosti in oblik. Prevladujoče oblike so zavese oziroma rebra, najdemo pa tudi kopaste tvorbe na spodnjih delih sten. Posebnost Velega Badina so tvorbe podobne jamskim stalaktitom, zaradi katerih so predhodni raziskovalci domnevali, da nastajajo z odlaganjem sige. V nasprotju od sigovih tvorb, katerih nastanek poteka v (načeloma) mikroklimatsko stabilnem okolju in ni vezan na prisotnost organizmov (abiotske tvorbe), lehnjakove tvorbe nastajajo na površju ob spremenljivih mikroklimatskih pogojih in s sodelovanjem organizmov (biotske tvorbe). Glede na značilnosti sodijo lehnjaki med poseben tip, tako imenovane lehnjakaste kapnike, $v$ tuji literaturi imenovane tufaceous speleothems (Taboroši 2002). Izraz »lehnjakast « v povezavi s temi tvorbami zasledimo pri slovenskem prevodu dela Dodge-Wan in Deng Hui Min (2013), zato ga pri opisu tvorb na preučevanih lokacijah tudi sami uporabljamo.

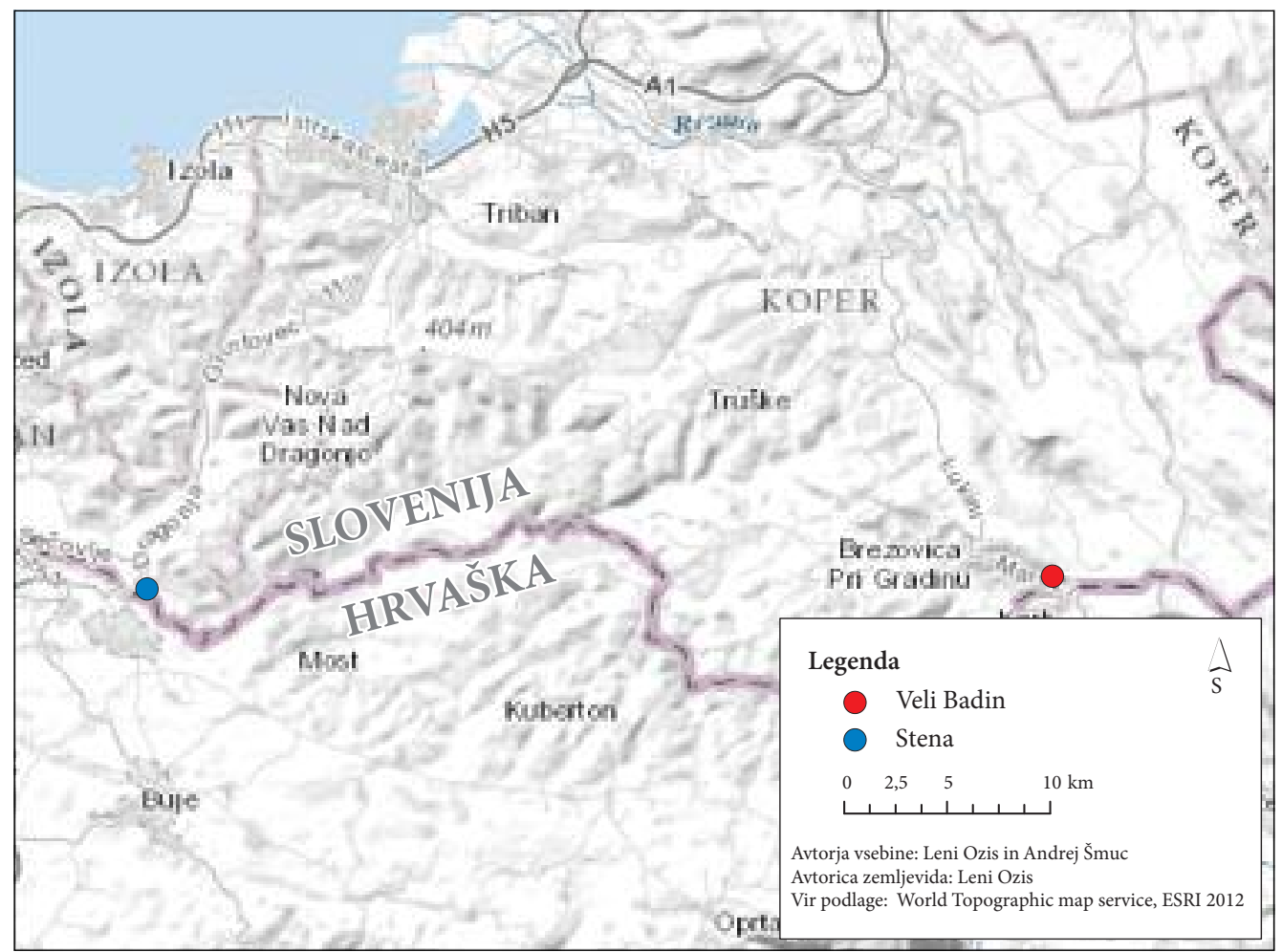

Slika 1: Lega preučenih lokacij z lehnjaki v spodmolih - Veli Badin in Stena v dolini Dragonje. 


\section{Metodologija}

Raziskava je obsegala tako terensko kot laboratorijsko delo, ki je bilo izvedeno med decembrom 2013 in februarjem 2014. Na izbranih lokacijah smo fotografirali različne tvorbe in zabeležili njihove posebnosti. Izmerili smo tvorbe, ki so bile dostopne za merjenje (stalaktitom podobne lehnjake smo izpustili). Na lokaciji Veli Badin smo opravili meritve 72 tvorb, na lokaciji Stena pa 49 tvorb. Merili smo premer in obseg tvorb ter delni obseg tvorb, ki se v zadnjem delu dotikajo stene. Na prvi lokaciji so bile izmere opravljene na višini $1,5 \mathrm{~m}$, na drugi pa na višini $1 \mathrm{~m}$. Obsege in premere smo merili s tračnim metrom, dolžino in višino pojavljanja na steni pa smo določali z laserskim merilnikom Leica DISTO D8. Na terenu smo odvzeli sedem vzorcev za nadaljnjo laboratorijsko analizo - štiri na lokaciji Stena in tri na lokaciji Veli Badin. Vzorčili smo zavese (rebra) in kopaste tvorbe. Težavnost odvzema se je med vzorci razlikovala. Nekateri so bili prhki in smo jih odvzeli brez težav, pri drugih je bil odvzem zahtevnejši. Vzorce smo v laboratoriju fotografirali, poskenirali in pripravili za nadaljnje analize. Za sedimentološko analizo smo izdelali 7 zbruskov. Za mineraloško in geokemično analizo smo vzorce $\mathrm{v}$ ahatni terilnici zmleli v fin prah (<63 mikronov). Mineralno sestavo smo določali z rentgenskim praškovnim difraktometrom (Philips, PW 1820), meritve smo opravili na neorientiranih prašnatih vzorcih ( $\mathrm{Cu} \mathrm{K} \mathrm{a} \mathrm{/} \mathrm{Ni} 40 \mathrm{kV}, 30 \mathrm{~mA}$ ). Rezultati meritev so bili prikazani s pomočjo računalniškega programa X'Pert HighScore. Geokemično analizo smo izvedli z rentgenskim fluorescenčnim analizatorjem (NITON, model XL3t GOLDD 900S-He). V procesu merjenja je bil uporabljen originalni proizvajalčev Mining filter. Na točko merjenja je bil načrpan helij $(\mathrm{He})$, ki omogoča boljše prepoznavanje lahkih elementov ( $\mathrm{Mg}, \mathrm{Si}, \mathrm{A}, \mathrm{S}, \mathrm{P})$. Čas merjenja vsake točke je bil 180 sekund.

\section{Splošno o lehnjakih}

\subsection{Pojem lehnjak in klasifikacija lehnjakov}

S pojmom lehnjak opisujemo sladkovodne biokemične sedimentne kamnine, ki nastajajo z izločanjem kalcita (tudi aragonita) ob močilih, izvirih, potokih, rekah in jezerih. Nastajajo v različnih podnebjih, njihovo odlaganje poteka lokalno, obsegajo pa lahko široka območja (Ford in Pedley 1996; Pentecost 2005; Pavšič 2006). So »nizke do srednje interkristalne poroznosti, s pogosto visoko moldično ali ogrodno poroznostjo (Pentecost 2005, 3). Za te sladkovodne karbonate v splošnem velja delitev na lehnjake (ang. tufa) in travertine (ang. travertine). Prvi so luknjičavi, močno porozni in z nizko gostoto, drugi so manj porozni (Herlec in Vidrih 2006). Razlikujejo se v temperaturi odlaganja kalcita in vrsti organizmov, ki sodelujejo pri tem. Lehnjaki se odlagajo v hladni vodi/v vodi s temperaturo blizu okoliške temperature, ob prisotnosti različnih tako mikro- kot makroorganizmov, travertini pa v vodi pri višjih temperaturah (termalna) in pod vplivom mikroorganizmov (Ford in Pedley 1996). Delitev na dva tipa je splošno sprejeta, dejansko pa med enim in drugim ni jasne meje (Herlec in Vidrih 2006). Pentecost (2005) oboje poimenuje kot travertin in $\mathrm{v}$ isto poimenovanje vključi tudi jamske sedimente - sige. $\mathrm{V}$ članku se pri poimenovanju tvorb, ki smo jih raziskovali v spodmolih, držimo »klasične« delitve in za sedimente, ki nastajajo v netermalni vodi ob prisotnosti različnih organizmov, uporabljamo izraz lehnjak. Iz tega izhajajo tudi izpeljanke za opis tvorb - lehnjakove tvorbe in lehnjakasti kapniki, pri čemer naše poimenovanje navezujemo na opise takšnih tvorb iz tuje literature, kot na primer lehnjakasti stalaktiti (ang. tufaceous stalactites) in lehnjakasti stalagmiti (tufaceous stalagmites) (Taboroši 2006; Dodge-Wan in Deng Hui Min 2013).

V preteklosti so obstajali različni poskusi klasificiranja lehnjakov glede na njihove značilnosti: glede na prisotnost rastlin (botanični pristop, na primer mahovni lehnjaki), glede na fizikalno-kemične in biokemične parametre, glede na lokacijo (geomorfološki pristop, na primer izviri in reke) in glede na facies (petrografski pristop) (Pedley 1990). Glede na slednjega lehnjake delimo na avtohtone in alothone. 
$\mathrm{V}$ našem primeru nas zanimajo avtohtoni (in situ) lehnjaki, in sicer fitohermni framestone-i in fitohermni boundstone-i. Framestone-i predstavljajo ogrodje makrofitov, pogosto naseljeno z biofilmom cianobakterij (modrozelenih cepljivk), kokoidnih bakterij, gliv in diatomej. Kalcit (tudi aragonit) se odlaga na stebla in liste rastlin. Ogrodje hitro razpada, nastaja visoko porozen material (poroznost nezapolnjenega materiala je lahko tudi več kot 90\% (Taboroši, Hirakawa in Sawagaki 2005)). Pore v ogrodju so pogosto zapolnjene s fitoklastičnim, mikritičnim in detritičnim lehnjakom. Boundstone-i, ki nastanejo po razpadu rastlin, za katerim ostanejo praznine in biofilmi, predstavljajo stromatolitske lehnjake cementirane površine mikrobov (Pedley 1990; Pentecost 2005; Sanders, Wertl in Rott 2011; Howie, Ealey in Anderson 2012).

\subsection{Vloga organizmov pri nastanku lehnjaka}

Nastanek lehnjaka je rezultat sodelovanja med fizikalno-kemičnimi in biološkimi procesi. Primarno je odlaganje lehnjaka vezano na izhajanje $\mathrm{CO}_{2}$ iz vode nasičene s kalcijevim karbonatom in spremembo temperature vode, vpliv pa imata tudi evaporacija in prisotnost organizmov, ki naj bi odlaganje pospeševala (Herlec in Vidrih 2006; Sanders, Wertl in Rott 2011). Vloga mikroorganizmov (bakterije, alge, glive) in makroorganizmov (mahovi, lišaji, višje rastline) pri nastajanju lehnjakov je lahko aktivna ali pasivna (Taboroši 2006). Aktivno naj bi organizmi pripomogli s številnimi kompleksnimi in povečini slabo razumljenimi procesi (Taboroši in Hirakawa 2004), med katerimi so aktivna biomineralizacija (neposreden vpliv) in fotosinteza, $\mathrm{s}$ katero organizmi odvzemajo $\mathrm{CO}_{2} \mathrm{iz}$ vode (posreden vpliv) (Taboroši 2002). Kljub temu pa je izhajanje $\mathrm{CO}_{2}$ vezano na biološke procese majhno v primerjavi s fizikalnim izhajanjem $\mathrm{CO}_{2}$ iz vode (Sanders, Wertl in Rott 2011). Po Pentecostu (1996) je nastanek lehnjaka v 6-12\% rezultat fotosinteze, $\mathrm{v} 10-20 \%$ evaporacije in v 70-80\% fizikalnega izhajanja $\mathrm{CO}_{2}$. V večji meri kot $\mathrm{z}$ aktivnim delovanjem, organizmi s svojim naseljevanjem vodnih virov predstavljajo različna ogrodja, na katera se anorgansko odlagajo karbonati in jih posledično inkrustirajo. V manjši meri prihaja tudi do bioerozije lehnjaka (Taboroši in Hirakawa 2004; Taboroši 2006).

Od mikro- in makroorganizmov so v potencialni povezavi z nastankom preučevanih lehnjakov v slovenski Istri vsi razen višjih rastlin. Na kratko so predstavljene splošne značilnosti biofilma in mahov.

Biofilm, do nekaj milimetrov debel mikrobni sloj, sestavljajo skupine celic bakterij, alg in gliv s svojimi produkti, ki naseljujejo matično kamnino, lehnjake in makrofite (Taboroši in Hirakawa 2004). Tip biofilma je odvisen od vlažnosti skale, zmožnosti pritrjevanja mikrobov nanjo in sodelovanja med različnimi vrstami mikrobov. Na biofilm vplivajo mikroklimatski pogoji - temperatura, vlažnost in stopnja osvetljenosti. Na dobro osvetljenih mestih nastajajo debeli sloji biofilma povezani $z$ lišaji in mahovi (Jones 2010). Z zmanjšanjem svetlobe in posledično možnostmi za fotosintezo se raznovrstnost biofilma zmanjšuje. Inkrustacije mikroorganizmov dajejo lehnjakom značilne strukture, ki so lahko laminirane, z nepravilnimi in nepovezanimi sloji, ali pa struktur ni prisotnih (Taboroši in Hirakawa 2003).

Mahovi (Bryophita) služijo kot ogrodja za abiotsko odlaganje karbonata, kot površine za naseljevanje biofilma, neposredno pa vplivajo na nastanek s fotosintezo (Sanders, Wertl in Rott 2011). V nasprotju od mikrobov je njihova rast omejena na območja s sončno svetlobo (Taboroši in Hirakawa 2004). Mahovi so sestavljeni iz treh delov: lističev, ki so blizu eden drugega, tankih nitastih stebelc in številnih riozid (koreninski sistem). Rizoide zagotavljajo dobro sidrišče, zato mahovi zdržijo visok stres in se ne odtrgajo zlahka, tudi iz strmih naklonov. Gostost lističev povečuje površino za odlaganje kalcita. Pri naseljevanju skalnih sten si hranila zagotavljajo s kapilarnim prehajanjem vode. S karbonatom nasičena voda na njihovi površini hitro izhlapeva, odlaganje kalcita pa je omejeno predvsem na spodnji del stebelc mahov. Mahovi se pogosto združujejo v gruče in inkrustacije med rastjo povečujejo stabilnost celotnih mahovnih gruč (Pentecost 2005). Skorjice, ki nastanejo z odlaganjem kalcita, povzročijo postopno odmrtje mahov, ti pa v kamnini pustijo svoj odtis, saj organska snov hitro razpade (Herlec in Vidrih 2006). 


\section{Lehnjakasti kapniki}

V zadnjem času najdemo v literaturi vedno več opisov lehnjakov, ki po obliki spominjajo na jamske kapnike. Podobni so jamskim stalaktitom, stalagmitom, stebrom, zavesam, lahko pa so tudi kopastih in nepravilnih oblik. Največkrat so lokacije teh »nejamskih « kapnikov v območjih s toplejšim podnebjem v jugovzhodni Aziji in Oceaniji: Tajska (Taboroši 2006), Malezija (Dodge-Wan in Deng Hui Min 2013) ter otoka Gvam in Tinian v Marijanskem otočju (Taboroši 2002). Zasledimo jih tudi v Angliji (Dalby 1966 v: Mulec, Kosi in Vrhovšek 2007), omenjeni pa so tudi pri nas - Schmidlova dvorana v Škocjanskih jamah (Mulec, Kosi in Vrhovšek 2007). Lehnjakasti kapniki se pojavljajo na jamskih vhodih, na skalnih stenah, ob razširjenih razpokah, na kraških stolpih, na spodnjih delih podornih blokov, na tektonsko dvignjenih abrazijskih spodmolih in drugih previsih (Taboroši, Hirakawa in Stafford 2004; Taboroši 2006). V nasprotju z drugimi tipi lehnjakov, ki lahko obsegajo tudi kilometrska območja, so veliki le do nekaj metrov, poleg tega naj bi organizmi pri njihovem nastanku imeli večjo vlogo, kot jo imajo pri nastanku drugih tipov lehnjakov (Taboroši in Hirakawa 2004; Taboroši, Hirakawa in Stafford 2004).

Princip nastanka lehnjakastih kapnikov je v glavnem isti kot tisti pri jamskih kapnikih. Glavna razlika je v mikroklimatskih značilnostih okolice; temperaturi, vlažnosti in osvetljenosti. Slednja vpliva na prisotnost organizmov in njihovo vlogo pri nastajanju teh kapnikov, kar jih ločuje od (praviloma abiotskih) sigovih tvorb v jamah (Taboroši in Hirakawa 2003). Kljub morfološki podobnosti lehnjakasti kapniki ne predstavljajo razpadajočih jamskih kapnikov, ko so ti z erozijo jamskih prostorov izpostavljeni površinskim procesom. Slednje še posebej velja za tvorbe, ki jih najdemo na podornih skalah (Taboroši, Hirakawa in Stafford 2004; Taboroši 2006).

Od vseh tipov lehnjakov je bilo največ pozornosti posvečene lehnjakastim stalaktitom/stalaktitskim lehnjakom/zunanjim stalaktitom (Taboroši 2002; Taboroši 2006), kompleksnim oblikam, zgrajenim iz korenin rastlin, mahov in stromatolitov, lahko iz vseh hkrati. Od jamskih stalaktitov se razlikujejo po svoji poroznosti, krušljivosti in velikem deležu organskega gradiva (Taboroši in Hirakawa 2004; Taboroši 2006). Po obliki so asimetrični zaradi rasti organizmov in posledičnega odlaganja karbonatov v smeri svetlobe ter vplivov zračnih tokov (Mulec, Kosi in Vrhovšek 2007). V konicah so lahko zaviti tudi stran od virov svetlobe, na kar naj bi vplivali mikroorganizmi (Taboroši in Hirakawa 2004). Za lokacije v slovenski Istri so pomembni tudi inkrustirani mahovi, ki po Taborošiju (2006) predstavljajo posebno kategorijo lehnjakastih kapnikov. Nastajajo pod osvetljenimi previsi in na tleh pod lehnjakastimi stalaktiti. Z zmanjševanjem svetlobe se njihova velikost zmanjšuje. Po obliki lahko spominjajo na kapnike, ni pa to nujno. Kadar so podobni stalaktitom, so v spodnjih delih lahko zaviti, saj na osvetljeni strani mahovi s svojo rastjo spodbujajo odlaganje kalcita (Taboroši in Hirakawa 2004; Taboroši 2006).

\section{Lehnjakove tvorbe v spodmolih v slovenski Istri}

\subsection{Splošne značilnosti lokacij lehnjakov}

Na lokaciji Veli Badin so spodmoli v apnenčastih stenah na jugozahodnem pobočju grebena Veli Badin-Krog. Stene so del Kraškega roba, ki je tektonsko prehodni pas med Jadransko-Apulijskim predgorjem in Zunanjimi Dinaridi. Za to pokrajino so značilne številne reliefne stopnje, kjer je na preperevanje odpornejši eocenski alveolinsko-numulitni apnenec narinjen na manj odporni eocenski fliš (Placer 2007; 2008). Stene Velega Badina so narivna cona s tremi obnarivnimi čelnimi gubami apnenca (Štefančič 2012), spodmoli pa se pojavljajo na stiku apnenec-apnenec. Nahajajo se v stenah na višini med 400 do $170 \mathrm{~m}$ in imajo pretežno jugozahodno ekspozicijo, $\mathrm{z}$ manjšimi odstopanji v smeri juga, jugovzhoda in zahoda. Glede na splošne podnebne značilnosti ima lokacija zaledno zmerno sredozemsko 
podnebje (srednja januarska temperatura je $0-4{ }^{\circ} \mathrm{C}$, srednja julijska temperatura je $20-22^{\circ} \mathrm{C}$ (Ogrin s sodelavci 2012)), zaradi ekspozicije pa imajo stene veliko osončenost, kar vpliva tudi na hitrejše izsuševanje. Drevesa in grmičevje $\mathrm{v}$ neposredni bližini sten $\mathrm{v}$ večini primerov ne prekrivajo spodmolov in nimajo vpliva na njihovo osončenost. Do sprememb v osončenosti prihaja na mikro ravni znotraj večjih spodmolov, kjer so zaradi njihove polkrožne oblikovanosti določene stene manj osončene. Spodmoli na Velem Badinu so največji v slovenski Istri. Največji med njimi merijo $20-25 \mathrm{~m}$ v širino, $10-13 \mathrm{~m} v$ višino in 10-15 m v globino (Ozis, Trpin in Šmuc 2014). Na stropih spodmolov, ki več metrov segajo v skalo, so nastali pogoji za oblikovanje lehnjakastih kapnikov podobnih jamskim stalaktitom, pojavljajo se tudi lehnjaki drugačnih oblik.

Druga lokacija, Stena v dolini Dragonje, je izdanek alveolinsko-numulitnih apnencev na stiku s flišem in aluvialnimi rečnimi sedimenti. Nahaja se na nižji nadmorski višini kot Veli Badin, približno $30 \mathrm{~m}$ nad morjem. Lokacija ni del podrivnega pasu (Placer 2007), temveč zahodni del bujske antiklinale (Pleničar, Polšak in Šikić 1973), od katere jo ločuje rečno korito Dragonje. Glede na podnebne značilnosti spada Stena v obalno zmerno sredozemsko podnebje (srednja januarska temperatura je nad $4^{\circ} \mathrm{C}$, srednja julijska temperatura je nad $22^{\circ} \mathrm{C}$ (Ogrin s sodelavci 2012)). Spodmoli imajo južno do jugozahodno ekspozicijo, kar ima za posledico veliko osončenost. Zmanjšujeta jo bujski greben, ki se nahaja južno od stene, in rastje, ki s krošnjami delno prekriva zahodni del stene. V nasprotju od spodmolov na Velem Badinu so spodmoli v Steni plitvi in široki (primer: $20 \mathrm{~m}$ širine, 3,5 m višine in 1,2 m globine). Stalaktitom podobne tvorbe se zaradi plitvosti spodmolov ne pojavljajo.

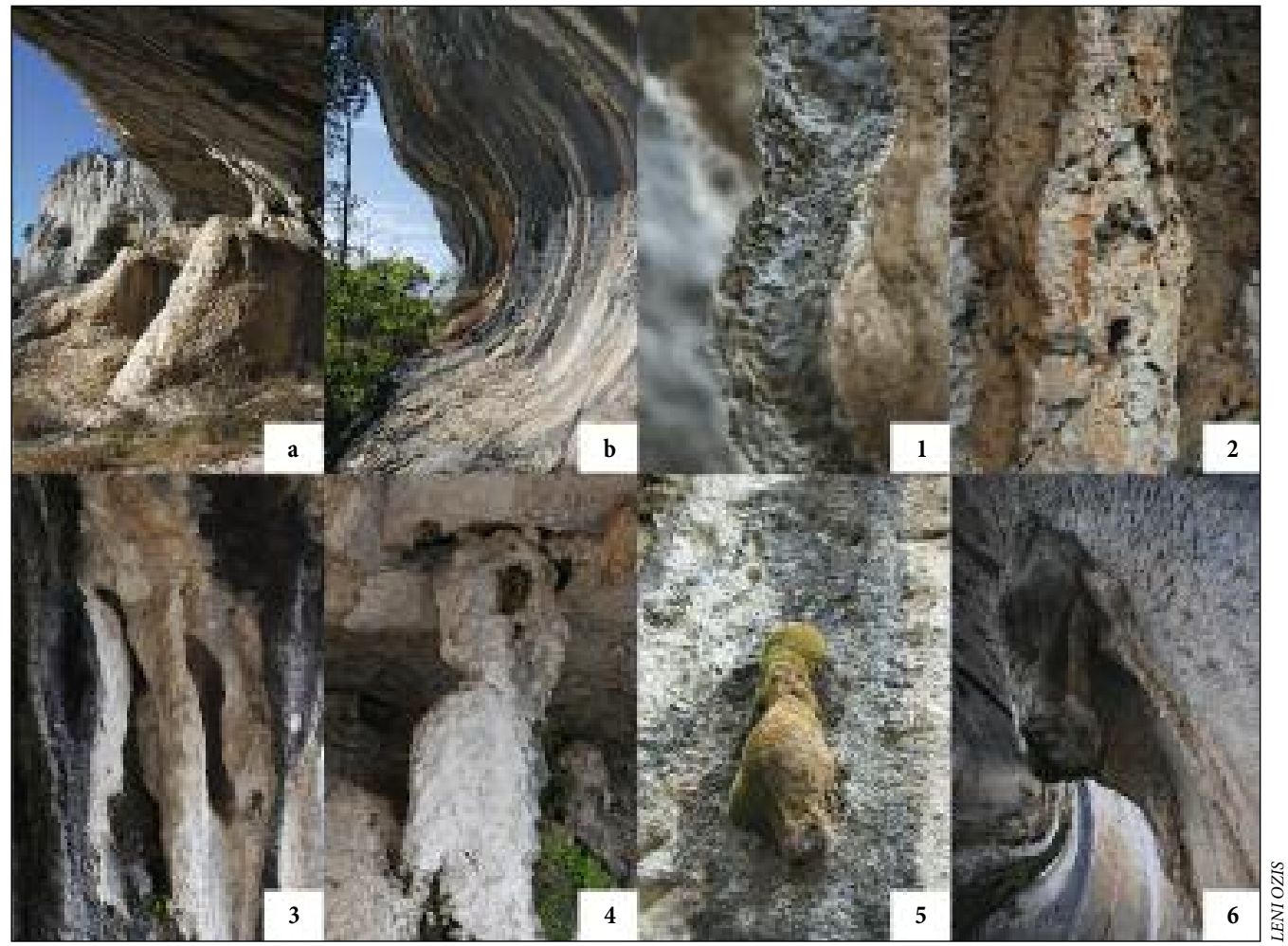

Slika 2: Spodmoli, v katerih se odlagajo lehnjaki: a - Veli Badin (VB) in b-Stena $v$ dolini Dragonje (SD). Različne oblike lehnjakovih tvorb: 1 - zavesa oziroma rebro (VB), 2 - kopasta tvorba (SD), 3 - skupina zaves (VB), 4 - steber (VB), 5 - tvorba v nastajanju (VB), 6 - tvorba, ki po obliki spominja na nos (VB). 


\subsection{Makroskopske značilnosti lehnjakov}

Oblika: Pojavljajo se tvorbe različnih oblik (slika 2 in slika 3). Na obeh lokacijah najdemo največ tvorb, ki delno spominjajo na jamske zavese (Taboroši, Hirakawa in Stafford 2004) in ki so jih predhodni raziskovalci spodmolov v slovenski Istri poimenovali rebra (Habič s sodelavci 1983; Natek s sodelavci 1993; Grmovšek 2001; 2002; 2003). Povečini se nahajajo pod stropom in nad dnom spodmolov, nekatere pa segajo izven stropov spodmolov na stene nad njimi. Po obliki niso tanke in vijugaste kot jamske zavese, ampak so podolgovate, s približno istim premerom po celotni dolžini. V prerezu imajo obliko polkroga. Nekatere potekajo v ravni liniji proti tlom, druge so zavite. V zgornjem in spodnjem delu so razširjene, lahko pa se spodaj zaključijo brez razširitve. Pogosto so združene v skupine. $\mathrm{Na}$ obeh lokacijah se pojavljajo tudi kopaste tvorbe v spodnjih delih sten, ki lahko predstavljajo razširjeno nadaljevanje reber ali pa so samostojne tvorbe. Na obeh lokacijah najdemo tudi lehnjakaste stebre. Lehnjak se na lokacijah odlaga tudi v oblikah podobnih tankim pramenom vode, pogoste pa so tudi nepravilne oblike in odlaganje lehnjaka na steno v tankih plasteh. Posebnost lokacije Veli Badin so stalaktitom podobne tvorbe in tvorbe, ki po obliki spominjajo na nos. Lehnjakasti stalaktiti se ne pojavljajo na zunanjem robu streh spodmolov, ampak so umaknjeni v notranjost. S konicami so lahko usmerjeni proti viru svetlobe, ali pa so usmerjeni proti tlom. Nosovom podobne tvorbe se nahajajo blizu ali na zadnjih stenah spodmolov. Podobno kot zavese se te tvorbe pogosto pojavljajo v skupinah, v nasprotju od zaves pa so v sredinskem delu odebeljene.

Velikost: Zavese oziroma rebra imajo na izmerjeni višini (VB $-1,5 \mathrm{~m}, \mathrm{SD}-1 \mathrm{~m}$ ) podoben premer, v povprečju med $15-20 \mathrm{~cm}$, njihov delni obseg od stene pa je v povprečju med $30-40 \mathrm{~cm}$. Tvorbe, ki po obliki spominjajo na nosove, so v srednjem delu odebeljene in v premeru merijo okoli $55 \mathrm{~cm}$, obseg od stene pa je okoli $125 \mathrm{~cm}$. Kopaste tvorbe smo merili na lokaciji Stena. Izmerjene tvorbe v premeru v povprečju merijo okoli $75 \mathrm{~cm}$, njihov obseg pa je lahko tudi več kot $200 \mathrm{~cm}$. Dolžina tvorb precej niha, pojavljajo pa se na različnih višinah na stenah. Na Velem Badinu se pri večjih spodmolih poleg lehnjakastih stalaktitov, ki se nahajajo na stropu ali malo pod njim, druge tvorbe pojavljajo na višini približno $3,5 \mathrm{~m}$ od tal, nekatere pa nižje približno $1,5 \mathrm{~m}$ od tal. Tvorbe so dolge med $0,7 \mathrm{~m}$ do $1 \mathrm{~m}$, nekatere merijo

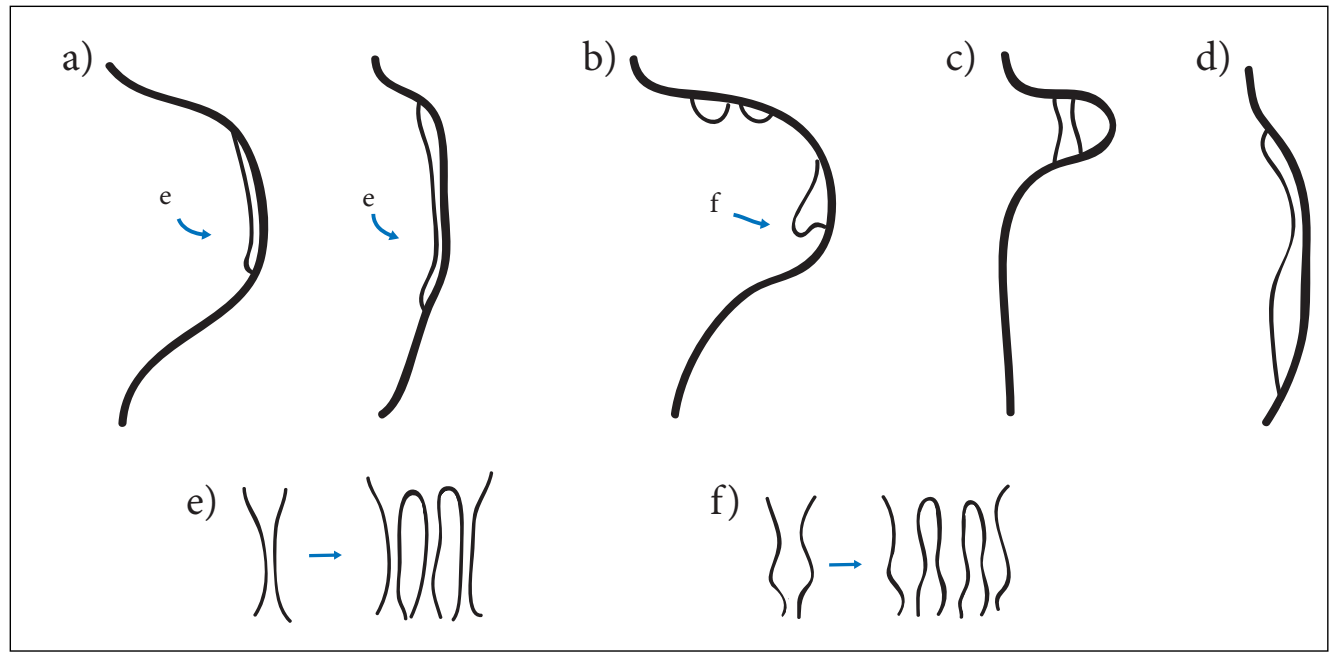

Slika 3: Tipi lehnjakovih tvorb: a - zavese (rebra), nahajajo se pod streho in nad dnom spodmolov (podolgovate in ozke; premer 15-20 cm) (VB in SD), b-stalaktitom podobne tvorbe in tvorbe, ki po obliki spominjajo na nos (VB), c - steber (VB in $S D$ ), d-kopaste tvorbe v spodnjem delu reber (VB in $S D$ ), $e$ - rebra so velikokrat združena $v$ skupine, $f$-tvorba, ki spominja na nos, tudi pogosto $v$ skupinah. 
tudi okoli $2 \mathrm{~m}$ (nosovom podobne tvorbe). Lehnjaki v plitvejših spodmolih na Velem Badinu segajo od stropa spodmolov do dna, podobno tudi na lokaciji Stena. Na tej lokaciji segajo nekatere tvorbe tudi izven stropov spodmolov in so tako dolge več kot $2 \mathrm{~m}$. Kopaste tvorbe segajo do višine $1 \mathrm{~m}$ od tal spodmolov.

Barva: Lehnjakove tvorbe so različnih barv: bele, sive, modro-sive, oranžne, temno sive, zelene, rjave in črne. Na barvo vpliva prisotnost organizmov, ki naseljujejo tvorbe. V notranjosti so svetlejših barv kot na površini: bele, svetlo sive, svetlo rjave in tudi svetlo oranžne (slika 4, oznaka a in b).

Prisotnost organizmov: Lehnjake naseljujejo alge, mahovi, lišaji in skupine različnih mikrobov (biofilm). Predstavljajo tudi habitate za živali, na primer nevretenčarje (polže).

Trdnost tvorb in prisotnost vode: Trdnost lehnjakovih tvorb precej variira. Nekatere tvorbe so krušljive in drobljive, nagnjene k luskanju in odpadanju s sten (odpade lahko tvorba v celoti), druge so trdne in na prvi pogled delujejo kot del stene in ne sekundarni sediment, v svoji notranjosti pa imajo značilno strukturo lehnjakov. Po nekaterih tvorbah mezi voda, druge so sušne in delujejo neaktivne. Odlaganje poteka na trenutno vlažnih delih sten, katere tudi naseljujejo organizmi, tvorbe, ki so sušne in na katerih ne poteka odlaganje, pa razpadajo.

Drobna površinska oblikovanost in poroznost: Površinska oblikovanost tvorb je zelo raznovrstna, saj je odvisna od odlaganja kalcita na različne organizme. Lehnjakove tvorbe so na površini lahko narebrene, grudičaste in luknjičaste, pojavljajo se skupki podobni majhnim grozdom, gomoljaste oblike, oblike podobne drobnim ponvicam (mikro terasam), ali pa je prisotno odlaganje lehnjaka v tankih plasteh brez posebnih oblik. V velikem številu se pojavljajo dobro vidni ostanki mahov. Prav tako je makroskopsko vidna poroznost tvorb, še bolj pa ta pride do izraza s skeniranjem vzorcev (slika 4, oznaka b).

\subsection{Mikroskopske značilnosti lehnjakov}

Sedimentološka analiza: Vsi preučeni vzorci glede na mikrofacies pripadajo avtohtonim lehnjakom. Nastali so kot posledica inkrustacije organizmov, ki so tvorili trdno ogrodje in jih štejemo med lehnjakaste boundstone. Večinoma gre za fitohermne lehnjake, nastale s kalcifikacijo makrofitov, večinoma mahov. Redkeje se pojavljajo tudi laminirani stromatolitni lehnjaki, ki so nastali zaradi delovanja mikrobnih organizmov. Na sliki 4 so s črko »c« označene fotografije zbruskov reprezentativnih tipov lehnjaka v spodmolih. Na mikroskopski sliki 1c stromatolitni lehnjak, sestavljen iz menjajočih se lamin svetlejšega sparita in temnejšega mikrita (zgornji del fotografije), prerašča fitohermni lehnjak (spodnji del fotografije). Mikroskopski sliki $2 \mathrm{c}$ in $3 \mathrm{c}$ prikazujeta kalcitizirane mahove v vzdolžnem prerezu. Na sliki 2c je mah delno kalcitiziran. Stebelca gradijo mikrosparitni kristali, ki vsebujejo malo organske snovi, medtem ko so predeli listov iz mikrita. Na sliki 3c je mah v kasnejši stopnji kalcifikacije. Črna polja nepravilnih oblik so ostanki organske snovi, bela polja pa pore. Stebelca so nadomestili sparitni kristali, liste pa mikrit.

Preglednica 1: Elementarna sestava preučenih lehnjakov.

\begin{tabular}{lrrrrrrrrrrrrrr}
\hline vzorec & \multicolumn{10}{c}{ koncentracije elementov v vzorcu (ppm) } \\
\hline & $\mathrm{CaO}$ & $\mathrm{MgO}$ & $\mathrm{SiO}_{2}$ & $\mathrm{Al}_{2} \mathrm{O}_{3}$ & $\mathrm{Fe}_{2} \mathrm{O}_{3}$ & $\mathrm{Sr}$ & $\mathrm{Ba}$ & $\mathrm{Ti}$ & $\mathrm{K}$ & $\mathrm{Al}$ & $\mathrm{P}$ & $\mathrm{Cl}$ & $\mathrm{S}$ \\
\hline $\mathrm{DR} 1$ & 536.045 & 2204 & 7760 & 1820 & 668 & 185 & 280 & 40 & - & 963 & & - & 1485 \\
$\mathrm{DR} 2$ & 547.088 & 2392 & 4245 & 536 & 375 & 198 & 320 & 52 & - & - & & 381 & 1478 \\
$\mathrm{DR} 3$ & 534.325 & 6258 & 1217 & 572 & 137 & 86 & 290 & - & - & - & & 2267 & 5109 \\
$\mathrm{DR} 4$ & 553.294 & 3 & 1699 & 663 & 265 & 58 & 288 & - & - & - & & - & 194 \\
$\mathrm{VB} 5$ & 549.348 & 1843 & 2908 & 670 & 184 & 190 & 327 & - & - & - & & - & 281 \\
$\mathrm{VB} 6$ & 540.430 & 362 & 10.426 & 1411 & 516 & 142 & 226 & 96 & 603 & 747 & 305 & 385 & 9284 \\
$\mathrm{VB} 7$ & 547.405 & 3 & 1259 & 915 & 139 & 260 & 317 & - & - & - & 1211 & - & 546 \\
\hline
\end{tabular}




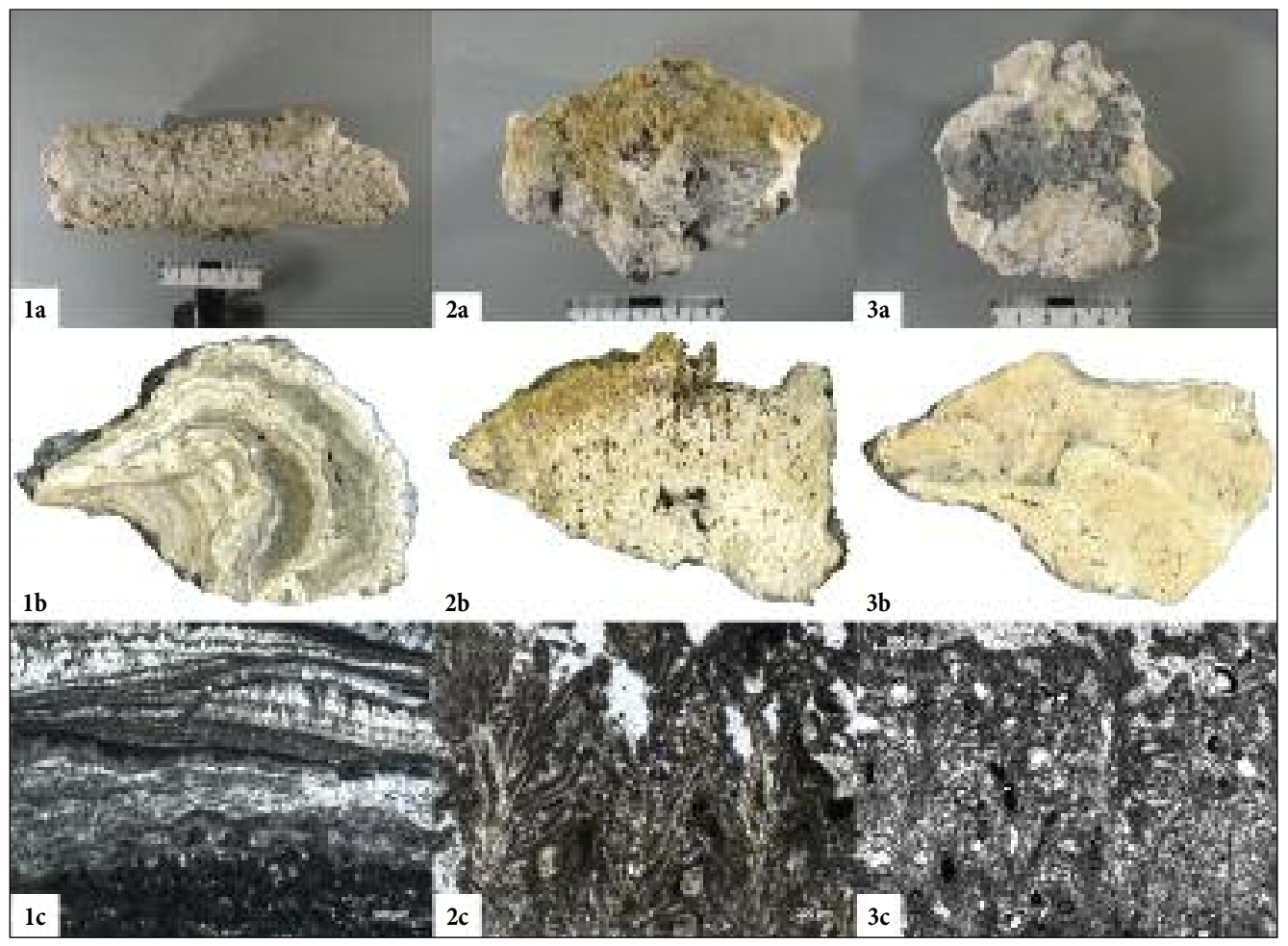

Slika 4: Trije reprezentativni vzorci lehnjaka iz spodmolov (1, 2 - SD, 3 - VB): a - fotografije odvzetih vzorcev (cm merilo), $b$ - skenirani vzorci lehnjaka v prerezu, $c$ - mikroskopska slika zbruskov vzorcev lehnjaka ( $\mu \mathrm{m}$ merilo).

Mineraloška in geokemična analiza: Mineralno sestavo lehnjakov določa en mineral - kalcit. Med elementi v vseh vzorcih lehnjakov prevladuje $\mathrm{CaO}$, katerega vsebnost je med 53-55\% (\% = ppm : 10.000). Količine drugih elementov (na primer $\mathrm{MgO}, \mathrm{SiO}_{2}$ ) se med vzorci razlikujejo (preglednica 1).

\section{Razprava}

Lehnjaki v preučenih spodmolih po morfologiji sodijo med lehnjakaste kapnike. Posamezni podtipi, ki se pojavljajo na izbranih lokacijah, so lehnjakasti stalaktiti, stebri, zavese oziroma rebra, kopaste tvorbe in druge oblike. V splošnem imajo podobne značilnosti kot lehnjakasti kapniki, opisani drugod po svetu, imajo pa v morfologiji nekaj posebnosti. Stalaktiti na primer niso linearni, podaljšani in masivni, kakršni se ponavadi pojavljajo na jamskih vhodih (Taboroši, Hirakawa in Stafford 2003), temveč bolj kroglasti - gomoljasti, in njihova dolžina dostikrat ne presega širine. Nastanek teh stalaktitov ni vezan na heterogeno kombinacijo organizmov (mikrobi, mahovi in višje rastline), pač pa glavne gradnike predstavljajo inkrustirani mahovi. Te lehnjakove tvorbe so v svojih spodnjih delih največkrat odebeljene in naseljene z živimi mahovi, lahko pa so tudi ožje in koničaste ter s tem bolj podobne »tipičnim « lehnjakastim stalaktitom. S konicami so tudi dostikrat usmerjene proti viru svetlobe in tako v nekaterih primerih rastejo skoraj pravokotno iz stene. Ne najemo pa primerkov, ki bi bili (pod vplivom mikroorganizmov) v konicah zaviti v smeri stran od svetlobe, kar je tudi ena od značilnosti lehnjakastih 
stalaktitov. Največji primerki lehnjakastih stalaktitov se glede na literaturo ponavadi pojavljajo na zunanjem robu kapljajoče vode, kjer poleg epikraške vode dobivajo tudi vodo, ki teče po zunanjih stenah nad previsom (Taboroši, Hirakawa in Stafford 2004). Slednje ne velja za stalaktite na Velem Badinu, saj se ti ne nahajajo na zunanjem robu stropa spodmolov, temveč so umaknjeni bolj v notranjost, na zunanjem robu pa večjih oblik ni zaslediti. Potrebne bi bile nadaljnje raziskave, da bi ugotovili razloge za njihovo odsotnost na zunanjem robu spodmolov. Opisa lehnjakovih tvorb, ki spominjajo na nosove, sicer nismo zasledili pri drugih avtorjih, omenjene pa so tvorbe, ki se delno držijo zadnjih sten, kar naj bi bila tudi ena od lastnosti določenih tipov lehnjakastih stalaktitov (Taboroši, Hirakawa in Stafford 2003). Druge oblike (zavese, kopaste tvorbe in stebri) se ne razlikujejo od opisov v literaturi, prav tako se preučeni lehnjaki ne razlikujejo od primerov po svetu po drugih značilnostih (na primer obarvanost, prisotnost organizmov, trdnost). Podobno je tudi glede značilnosti na mikro ravni. V prerezih tvorb se pojavljajo inkrustirani mahovi in mikroorganizmi, ki preraščajo mahove. Mikrobno gradivo je amorfno ali laminirano, pri čemer so lamine nepravilne in vijugaste, in se tako razlikujejo od pravilno razporejenih lamin pri jamskih kapnikih. V laminah se izmenjujeta temnejši mikrit in svetlejši sparit. Pri ostankih mahov kalcit zapolnjuje nekdanja organska ogrodja, tako da sparit nadomešča stebelca, mikrit pa ostanke listov. Vzorci variirajo od visoko poroznih do manj poroznih. Manjša poroznost je rezultat delovanja mikroorganizmov in kasnejše kalcifikacije v notranjosti. S sekundarnimi zapolnitvami por se manjša prvotna poroznost lehnjakov, kar se najbolje vidi v primerjavi vzorcev »mlajših" (nedavno kalcificiranih, $\mathrm{z}$ dobro vidnimi ostanki rastlin) lehnjakov in »starejših " (organsko gradivo je nadomestil kalcit, sledi ogrodja so ostale) lehnjakov.

Vzorci preučenih tvorb so kljub morfološkim podobnostim z jamskimi kapniki zgrajeni iz materialov, ki gradijo druge tipe lehnjakov. Tako se na primer pojavljajo manjši in poljubno usmerjeni kristali kalcita zaradi hitrejšega odlaganja in velik delež rastlinskih ostankov. Prepletanje med anorganskim in organskim materialom, do katerega prihaja pri vsakem primerku, je značilno za vse tipe lehnjakov in lehnjakasti kapniki pri tem niso izjema. Laboratorijske raziskave so naše ugotovitve s terena tako potrdile še na mikro ravni.

\section{Sklep}

$\mathrm{Z}$ raziskavo karbonatnih tvorb na spodmolih Veli Badin in Stena smo potrdili domnevo, da ne gre za sige, temveč lehnjake, in sicer »lehnjakaste kapnike«. Te tvorbe nastajajo po istih osnovnih principih kot jamski kapniki, razlike v mikroklimatskih značilnostih okolja odlaganja pa vplivajo na njihove značilnosti, tako na makro kot na mikro ravni. Zanje lahko uporabljamo ista poimenovanja kot za kapnike v jamah, le da jim dodamo pridevnik »lehnjakast «. Pri nastanku preučenih lehnjakov imajo vlogo tako mahovi kot mikroorganizmi, katerih inkrustirani ostanki se izmenjujejo v zbruskih odvzetih vzorcev lehnjaka. Mahovi predstavljajo glavne gradnike večine tvorb in tako kot pri primerih lehnjakastih kapnikov po svetu ne služijo le kot pasivno ogrodje za odlaganje, ampak s svojo rastjo proti svetlobi določajo tudi nadaljnjo oblikovanost tvorb. Organizmom lahko torej pripišemo večjo vlogo pri nastanku tega tipa lehnjaka $\mathrm{v}$ primerjavi $\mathrm{z}$ ostalimi tipi lehnjakov.

Odkritje, da se v spodmolih odlagajo lehnjaki, prinaša tudi nove ugotovitve glede samih spodmolov. Ker na njihovih stenah ne najdemo sigovih tvorb, lahko opustimo domneve, da je v njihovem razvoju potreba tudi zaprta faza, ki bi ustvarila pogoje za odlaganje sige, kot navajajo predhodne raziskave (Gogala 2007). Poleg tega mahovni lehnjaki, ki na preučenih lokacijah prevladujejo, lahko nastajajo le v dovolj osvetljenih okoljih. Glede na to, da na lokacijah najdemo primerke velike tudi do $2 \mathrm{~m}$, spodmoli predstavljajo dobro osvetljena okolja, v katerih se lahko odlagajo lehnjaki. Kljub morfološki podobnosti pri preučenih primerih ne gre za na površju razpadajoče jamske kapnike, pač pa slednjim podobne lehnjake, ki nastajajo v sedanjem času. Spodmoli tako glede na morfologijo predstavljajo polodprti prostor tudi v predhodnih fazah njihovega nastanka. 
V prihodnje bi bilo smiselno razširiti raziskovanje lehnjakastih kapnikov na druga območja v slovenski Istri in pri tem analizirati večje število vzorcev lehnjaka. Treba bi bilo tudi podrobneje preučiti organizme, ki so prisotni pri njihovem odlaganju, da bi lahko izvedeli več o njihovi vlogi pri nastanku lehnjakov. Dodatne raziskave bodo morda tudi ponudile odgovor na vprašanje, zakaj se lehnjakasti kapniki na območju slovenske Istre pojavljajo v tako velikem številu.

\section{Viri in literatura}

Dalby, D. H. 1966: The growth of plants under reduced light. Studies in Speleology 1-4. Hoboken.

Dodge-Wan, D., Deng Hui Min, A. 2013: Biologically influenced stalagmites in Niah and Mulu caves

(Sarawak, Malaysia). Acta carsologica 42-1. Ljubljana. DOI: http://dx.doi.org/10.3986/ac.v42i1.634

Ford, T. D., Pedley, H. M. 1996: A review of tufa and travertine deposits of the world. Earth Science Reviews 41. Amsterdam. DOI: http://dx.doi.org/10.1016/S0012-8252(96)00030-X

Gogala, A. 2007: Spodmoli na Velem Badinu - jama brez stene? Proteus 69-8. Ljubljana.

Grmovšek, A. 2001: Morfologija sten Kraškega roba. Diplomsko delo, Filozofska fakulteta Univerze v Ljubljani. Ljubljana.

Grmovšek, A. 2002: Manj znane reliefne oblike v stenah kraškega roba. Geografski obzornik 49-3. Ljubljana.

Grmovšek, A. 2003: Zgodbe iz življenja oprimkov: o nastanku in geomorfologiji stenskih reliefnih oblik. Planinski vestnik 103-4. Ljubljana.

Habič, P., Gospodarič, R., Mihevc, A., Šušteršič, F. 1983: Movraška in Smokovska vala ter Jama pod Krogom. Acta carsologica 11. Ljubljana.

Herlec, U., Vidrih, R. 2006: Lehnjak. Scopolia, Supplementum 3. Ljubljana.

Howie, F. M. P., Ealey, P. J., Anderson, J. 2012: Tufa, tufa-cemented rockfalls and speleothems of Newtrain Bay, North Cornwall. Geoscience in South-West England 13-1. Redruth.

Jones, B. 2010: Microbes in caves: agents of calcite corrosion and precipitation. Tufas and Speleothems: Unravelling the Microbial and Physical Controls. London. DOI: http://dx.doi.org/10.1144/SP336.2

Kunaver, J. 2007: Ponovno o spodmolih na Velem Badinu in njihovem nastanku. Proteus 69-9. Ljubljana.

Kunaver, J., Ogrin, D. 1992: Exfoliation-generated rock shelters in limestone escarpments in western Dinaric Slovenia. Geomorphology and the Sea, international symposium and the meeting of the geomorphological commision of the Carphato-Balkan countries. Zagreb.

Kunaver, J., Ogrin, D. 1993: Spodmoli v stenah kraškega roba. Annales 3-3. Koper.

Mulec, J., Kosi, G., Vrhovšek, D. 2007: Algae promote growth of stalagmites and stalactites in karst caves (Škocjanske jame, Slovenia). Carbonates and Evaporites 22-1. Berlin Heidelberg. DOI: http://dx.doi.org/ 10.1007/BF03175841

Natek, K., Žumer, J., Ogrin, D., Topole, M., Hrvatin, M., Gabrovec, M. 1993: Geomorfološka inventarizacija Kraškega roba. Elaborat, Geografski inštitut Antona Melika ZRC SAZU. Ljubljana.

Ogrin, D., Vysoudil, M., Mrak, I., Ogrin, M. 2012: Splošne in lokalne podnebne poteze. Geografija stika Slovenske Istre in Tržaškega zaliva. Ljubljana.

Ozis, L., Trpin, J., Šmuc, A. 2014: Rock shelters in Slovenian Istria as a potential for the development of geotourism in the region. Geologija 52-2. Ljubljana. DOI: http://dx.doi.org/10.5474/geologija.2014.018

Pavšič, J. (ur.) 2006: Geološki terminološki slovar. Ljubljana.

Pedley, H. M. 1990: Classification and environmental models of cool freshwater tufas. Sedimentary Geology 68. Amsterdam. DOI: http://dx.doi.org/10.1016/0037-0738(90)90124-C

Pentecost, A. 1996: Moss growth and travertine deposition: the significance of photosynthesis, evaporation and degassing of carbon dioxide. Journal of Bryology 19. Northampton.

Pentecost, A. 2005: Travertine. Berlin 
Placer, L. 2007: Kraški rob: geološki prerez vzdolž AC Kozina - Koper. Geologija 50-1. Ljubljana. DOI: http://dx.doi.org/10.5474/geologija.2007.003

Placer, L. 2008: Principles of the tectonic subdivision of Slovenia. Geologija 51-2. Ljubljana. DOI: http://dx.doi.org/10.5474/geologija.2008.021

Pleničar, M., Polšak, A., Šikić, D. 1973: Osnovna geološka karta SFRJ $1: 100.000$, tolmač lista Trst. Zvezni geološki zavod. Beograd.

Sanders, D., Wertl, W., Rott, E. 2011: Spring-associated limestones of the Eastern Alps: overview of facies, deposystems, minerals, and biota. Facies 57. Berlin. DOI: http://dx.doi.org/10.1007/s10347-010-0252-y

Štefančič, M. 2012: Detajlno geološko kartiranje Velikega Badina. Seminarska naloga, Naravoslovnotehniška fakulteta Univerze v Ljubljani. Ljubljana.

Taboroši, D. 2002: Biokarst on a tropical carbonate island: Guam, Mariana Islands. Theoretical and Applied Karstology 15. Bukarešta.

Taboroši, D. 2006: Biologically influenced carbonate speleothems. Geological Society of America Special Papers 404. Washington. DOI: http://dx.doi.org/10.1130/2006.2404(26)

Taboroši, D., Hirakawa, K. 2003: Microclimate controls of vadose carbonate precipitation: evidence from stalactite morphology. Theoretical and Applied Karstology 16. Bukarešta.

Taboroši, D., Hirakawa, K. 2004: Biota and biological processes associated with subaerial tufa stalactites in the tropics. Cave and Karst Science 31-2. Buxton.

Taboroši, D., Hirakawa, K., Sawagaki, T. 2005: Carbonate precipitation along a microclimatic gradient in a Thailand cave - continuum of calcareous tufa and speleothems. Journal of Cave and Karst Studies 67-1. Huntsville.

Taboroši, D., Hirakawa, K., Stafford, K. 2003: Speleothem-like calcite and aragonite deposits on tropical carbonate coast. Cave and Karst Science 30-1. Buxton.

Taboroši, D., Hirakawa, K., Stafford, K. 2004: Subaerial tufa in the Mariana Islands and its depositional settings. Studies in Speleology 13. Hoboken.

\section{Summary: Tufaceous speleothems in rock shelters in Slovenian Istria}

(translated by Leni Ozis and Katarina Pinosa)

Rock shelters are a common geomorphological characteristic of the Slovenian Istria. The distinct feature of these rock shelters is that the host limestone rock is frequently overlain by freshwater calcareous deposits that cover the inner walls and roofs of rock shelters. Up until now these deposits were described as different forms of speleothems: stalactites, flowstone ribs, draperies, domed formations and flowstone crusts. The presence of speleothems in a semi-open space of rock shelters encouraged previous researchers to assume that a »cavelike« (less open) stage is necessary in the morphogenesis of these rock shelters.

Our study was aimed at the detailed description and interpretation of these calcareous formations at two rock shelters locations: Veli Badin and Stena in Dragonja Valley. Rock shelters at both locations have their walls and roofs covered with numerous calcareous deposits of different sizes and forms. Mosses, bacteria and algae colonize these deposits and moisture outlets on the walls of rock shelters. Different formations were photographed and measured in the field, an inventory of the specifics of formations was made and samples of the deposits were collected for further laboratory investigations. To examine the structure and composition of the samples, petrological and sedimentological analyses with an optical microscope were made. The mineral and chemical composition of the samples was determined with X-ray powder diffraction and X-ray fluorescence (XRF).

A more detailed overview of rock shelter walls in the field showed that in contrast to the existing assumptions, formations are actually tufas. They represent a special type of tufa, the so-called tufaceous speleothems. This type of tufa has been of interest to scientists from different parts of the world in the 
past couple of years. Tufaceous speleothems in their morphology resemble cave speleothems, since the basic principles of their formation are the same as those of "classical « speleothems. But these "outer" speleothems still differ from the "inner " speleothems in caves. In contrast to a relatively stable microenvironment in caves, the deposition of secondary deposits in a semi-open space of rock shelters is under the influence of variations in microclimatic conditions. Changes in temperature, humidity and especially light intensity, which affects the growth of the organisms (microbial organisms, mosses etc.), determine the morphology of tufaceous speleothems. Organisms have a considerable role in the formation of these calcareous deposits, therefore we can describe them as biotic formations in contrast to abiotic speleothems in caves. At the two studied locations tufas display diverse morphologies. We observed the following morphological types of tufa: tufaceous stalactites, columns, draperies or ribs, domed formations, nose-like tufa formations and other irregular forms of tufa. Tufaceous draperies or ribs, formed (mostly) below roofs and above the grounds of rock shelters, prevail at both locations. They are elongated and narrow in shape and often occur in groups. At both locations also columns and domed formations occur. The latter are found in the lower parts of rock shelter walls. They represent widened parts of draperies at their bottom, or can be individual formations. Tufas similar to cave stalactites and nose-like formations are found only at the location Veli Badin, where rock shelters have distinctively formed roofs, but are not present at the location Stena, where rock shelters are shallow in their transverse profile. In general, investigated tufas have similar characteristics as tufaceous speleothems from other parts of the world, yet they have some special features. For example, stalactites do not occur at the most outer part of rock shelter roofs but are found closer to the back walls of rock shelters. They are not linear and elongated, but circular and bulbous in shape, in some cases their length is only slightly longer than their width. Nose-like tufas are maybe a subtype of stalactites, as other authors found samples of stalactites partly attached to walls in cavities, or a special morphological type. But except these two morphologic types, other tufaceous speleothems do not differ much from the descriptions in literature. The same is with other characteristics of these tufas. They are of different colours (white, orange, gray, bluish-gray, dark gray, green, brown and black) and sizes (but do not exceed the size of a few metres), covered by microorganisms (bacteria, algae, fungi) and macroorganisms (mosses and lichen). Tufas can be either fragile, crumbly and prone to flaking and falling off the walls, or solid and sometimes hardly recognizable as secondary sediment and not part of a host rock. They can be dry and seem inactive or wet with active deposition of carbonate minerals on their surface. The shape of their surface varies from easily recognizable remains of mosses to ribbed, lumpy, bulbous, grape-like shapes, and shape similar to small rimstones (microterracettes). Their porosity can often be seen with the naked eye and in more detail with scanning of samples.

With laboratory analyses we investigated these deposits on the micro level. The mineralogical content of the sampled tufas is defined by one mineral, calcite, and the elemental composition of all tufa samples is dominated by $\mathrm{CaO}$. According to microfacies these deposits belong to the autochthonous tufa and were formed due to in situ encrustation of organisms which form a rigid framework exhibiting tufa boundstone facies. Mainly they are phytohermal tufas represented by encrusted macrophytes (mosses) in growth position, however in places also stromatolitic tufa are present that are characterized by laminated deposits built by microbal communities. Porosity of samples varies from highly porous remains of mosses, to less porous laminated or amorphous microbial material. Combinations of organic material, micrite and sparite occur in all tufa samples. Micrite can be found on the leafy parts of encrusted mosses and as a darker laminae of stromatolitic tufa, while sparite crystals represent lighter laminae of stromatolitic tufa and remains of mosses steams. The interlacing of organic and inorganic material is typical for all types of tufa, thus the investigated tufas are not an exception.

Laboratory investigations along with field work confirmed our assumptions that calcareous deposits covering the walls of rock shelters are tufas. Organisms, especially mosses, have in our opinion an important role in their formation, or at least they participate in it more actively than organisms interlinked with other types of tufa. Our discovery also gives new insights into the understanding of 
the morphogenesis of rock shelters in Slovenian Istria. Despite the morphological similarity of these deposits to cave speleothems, they are not indicators of former cavities, as they can be formed only in well illuminated environments. The presence of tufas on rock shelter walls indicates that these landforms in previous formation phases morphologically represented a semi-open space. 